\title{
Pendidikan Tinggi sebagai Arena Transformasi Pembangunan Wilayah BARSELA; Antara Peluang dan Tantangan.
}

\author{
Penulis : \\ Akmal Saputra, S.Sos I., MA \\ Sosiologi FISIP-Universitas Teuku Umar \\ Email: akmalsaputra@utu.ac.id
}

\begin{abstract}
This article based on the reality of development in West Aceh. West Aceh is currently being intensively undertaken development on various sectors, one of them in the education sector. This article aims to examine how development opportunities and challenges are in the education sector, why is development in the education sector important?, also to examine what and how the role of academics in development of education sector ?. Research method used in this article is literature review. The approach is Improvement Approach and Tranformation Approach. The result of the research shows that the role of academics is considered very important to advance education in Barsela region, especially West Aceh. The role of academic can be shown through the implementation of tri darma of higher education; education, research and community service. Academics have an important role to change the mindset of society interested in continuing higher education. In additio, academics and government must synergize in conducting development programs, especially in education. Education is the spearhead of development, higher education as an arena of development transformation has a big chance, but has many challenges, one of the public interest towards universities is still considered less and people still have the mindset that universities need is expensive. This mindset has become a habitus in some people who are in the middle to lower class, whereas society is the subject of development.
\end{abstract}

Keywords: Higher Education, Development Transformation, Opportunities and Challenges

\section{PENDAHULUAN}

Artikel ini berangkat dari realitas pembangunan di Aceh Barat saat ini, Aceh Barat sedang giat-giatnya melakukan pembangunan pada berbagai sektor, terutama pada sektor pendidikan. Penulis mencoba melihat pembangunan Aceh Barat sebagai sebuah transformasi menuju Aceh Barat yang madani, penulis akan fokus melihat pembangunan pada sektor pendidikan. Aceh Barat saat memiliki 3 (tiga) perguruan tinggi negeri, yaitu Universitas Teuku Umar, STAIN Tengku Dirundeng dan Akademi Komunitas Negeri, selain itu juga memiliki perguruan tinggi swasta yang kedua-duanya merupakan motor penggerak bagi pembangunan di Aceh Barat. Aceh Barat merupakan salah satu wilayah BARSELA 
(Barat Selatan Aceh) yang sedang gencar-gencarnya melakukan pembangunan melalui pengembangan di sektor pendidikan. Pembangunan yang sedang dijalankan tentu saja memiliki berbagai tantangan dan juga peluang. Tulisan ini akan fokus mengkaji apa yang menjadi tantangan dan peluang pembangunan di sektor pendidikan? Mengapa pembangunan di sektor pendidikan menjadi penting? apa dan bagaimana peran akademisi pada pembangunan pada sektor pendidikan?

Mengenai pendidikan non formal di Aceh Barat berjalan dengan baik dan diminati oleh masyarakat, dapat diamati adanya pesantren dan dayah-dayah tradisional (Jarmita, 2016), selain itu juga sedang berjalannya program pemerintah pusat melalui Undang-Undang Desa yang kemudian di implementasikan dengan program-program pendidikan non formal di gampong, misalnya pelatihanpelatihan soft skill untuk meningkatkan perekonomian masyarakat dapat diamati di Kecamatan Meureubo yang tidak jauh dari pusat kota dan pusat perguruan tinggi.(Syahputri \& Liyana, 2017).

Aceh Barat merupakan salah satu kabupaten yang termasuk dalam provinsi Aceh. saat ini Provinsi Aceh memiliki 23 Kabupaten/Kota. Kabupaten Aceh Barat termasuk salah satu kabupaten yang tertua di wilayah barat selatan (BARSELA) Aceh. Kabupaten Aceh Barat sendiri telah mekar dalam beberapa Kabupaten, yaitu Nagan Raya, Aceh Jaya, Simeulue dan kabarnya akan ada satu lagi yaitu Kota Meulaboh. Aceh Barat merupakan salah satu wilayah yang memiliki potensi sumberdaya alam yang melimpah, baik kekayaan hutan, laut dan tambang. Di Aceh Barat hari ini telah berdiri perusahaan tambang batu bara yaitu PT. Mifa Bersaudara dan beberapa perusahaan perkebunan sawit. Hasil hutan dan laut juga melimpah, di Aceh Barat akan mudah sekali kita menemukan hasil tangkapan nelayan di laut yang masih segar dan beragam jenis ikan yang dapat di nikmati oleh masyarakat Aceh Barat dan sekitarnya. Aceh Barat memiliki ibu kota yang luasnya tergolong sangat kecil, namun di sana hidup masyarakat yang sangat multikultural dan sangat harmonis sekaligus memiliki profesi yang sangat beragam pula, baik sebagai pedagang, nelayan, petani, pegawai di perusahaan dan juga pegawai negeri sipil, dosen, guru, dokter, bidan, perawat dan berbagai profesi lainnya.

Wilayah pantai barat-selatan Aceh yang dikenal dengan istilah Barsela, termasuk salah satunya Aceh Barat yang sebelumnya termasuk wilayah yang tertinggal dalam pembangunan dibandingkan dengan wilayah pantai utara dan 
timur Aceh. ketertinggalan itu di akibatkan oleh ketidakmerataan pembangunan di Aceh pada masa lalu, hal ini dapat kita buktikan dengan melihat bagaimana perkembangan pendidikan tinggi di wilayah Aceh Barat, padahal wilayah Barsela secara administratif memiliki wilayah yang sangat luas, yaitu Aceh Barat, Aceh Jaya, Nagan Raya, Simeulue, Aceh Barat Daya, Aceh Selatan, Aceh Singkil, di sana tidak ada satu pun kita temukan perguruan tinggi negeri sebelumnya. Baru beberapa tahun terakhir saja di wilayah Aceh Barat baru berdiri tiga perguruan tinggi negeri yaitu Universitas Teuku Umar, STAIN Tengku Dirundeng dan Akademi Komunitas Negeri. Perguruan tinggi swasta memang telah lama ada, namun belum mampu memberikan kualitas yang terbaik untuk perkembangan pendidikan di Barsela, hal ini tentu saja ada faktor yang beragam dan persoalan masing-masing, namun kehadiran kampus-kampus swasta sebenarnya juga faktor pendukung untuk kemajuan Aceh Barat dan Barsela. Universitas Teuku Umar dan STAIN Tengku Dirundeng juga awalnya berstatus swasta kemudian bertransformasi menjadi perguruan tinggi negeri.

Untuk menjadi dan mencapai keadaan yang sejahtera dan makmur tentu saja banyak hal yang harus diperbaiki, terutama pembangunan di sektor pendidikan. Persoalan-persoalan yang ada di Aceh Barat tentu sangat beragam, mulai birokrasi pemerintahan, politik, ekonomi, sampai pada kondisi sosial dan budaya masyarakat. Perbaikan itu sendiri membutuhkan proses dan waktu yang cukup panjang, tidak semudah membalikkan telapak tangan, tantangan dan peluang akan hadir secara bersamaan, tidak mudah mengubah kebiasaan dan pola pikir masyarakat yang sudah tertanam sejak lama dan telah menjadi habitus, tidak mudah mengubah pola birokrasi pemerintahan yang sudah dikembangkan sejak lama. Semuanya memiliki tantangan yang cukup besar. Berangkat dari pendahuluan di atas, penulis mencoba untuk menganalisis, apa yang menjadi peluang dan tantangan untuk pembangunan Aceh Barat pada sektor pendidikan? Mengapa pembangunan di sektor pendidikan menjadi penting? apa dan bagaimana peran akademisi pada pembangunan di sektor pendidikan?

\section{TINJAUAN PUSTAKA}

Sebelumnya telah ada penelitian tentang Pemahaman Masyarakat Terhadap Pendidikan (Studi Pada Masyarakat Asoe Lhok di Aceh Barat) yang diteliti oleh Nida Jarmita (Jarmita, 2016), beliau mencoba mengungkapkan bagaimana pemahaman 
32

Community: Volume 4, Nomor 1, April 2018

ISSN: 2477-5746

dan minat masyarakat terhadap pendidikan tinggi? Tulisan Nida Jarmita, hanya menganalisis pada pemahaman dan minat masyarakat terhadap pendidikan tinggi. Hasil penelitiannya menunjukkan minat masyarakat Asoe Lhok di Aceh Barat terhadap pendidikan tinggi masih sangat kurang dan justru perguruan tinggi di isi oleh masyarakat pendatang dari berbagai kabupaten di Barsela. Masyarakat Asoe Lhok menganggap bahwa untuk melanjutkan ke perguruan tinggi membutuhkan biaya yang tidak sedikit, justru perguruan tinggi kemudian di isi oleh masyarakat pendatang dari berbagai kabupaten di Barsela dan juga kabupaten di luar Barsela. Berbeda dengan penelitian Nida Jarmita, penulis fokus pada kajian apa yang menjadi peluang dan tantangan untuk pembangunan Aceh Barat pada sektor pendidikan? Mengapa pembangunan di sektor pendidikan menjadi penting? apa dan bagaimana peran akademisi pada pembangunan pada sektor pendidikan?

Berikutnya penelitian Teuku Syarifuddin (Syarifuddin, 2016) tentang Kontribusi Perguruan Tinggi dalam proses Pembangunan Bidang Kesejahteraan Sosial, beliau menjelaskan bahwa perguruan tinggi memiliki peran penting untuk pembangunan, penelitian beliau hanya fokus pada pembangunan bidang kesejahteraan sosial, sedangkan topik yang penulis bahas adalah apa yang menjadi peluang dan tantangan untuk pembangunan Aceh Barat pada sektor pendidikan? Mengapa pembangunan di sektor pendidikan menjadi penting? apa dan bagaimana peran akademisi pada pembangunan pada sektor pendidikan?

Berikutnya Penelitian (Vina Salviana Darvina Soedarwo, Nurul Zuriah, Ratih Yuliati, 2017) tentang Pemberdayaan Masyarakat melalui pendidikan non formal Berbasis Potensi Lokal Dalam Membangun Desa Wisata Adat. Ada dua kata kunci dalam kajian ini, yaitu pemberdayaan dan pendidikan non formal yang melatih skill masyarakat, menurutnya pendidikan non formal ini bertujuan untuk mengembangkan potensi yang ada pada masyarakat melalui program pemberdayaan masyarakat dengan tujuan agar masyarakat mandiri dan terberdaya. Penelitian ini secara tersirat juga bicara pada pendidikan dengan tujuan untuk menjadikan masyarakat yang madani dan mandiri, namun berbeda dengan penelitian yang penulis lakukan, penulis mengkaji pendidikan formal khususnya pendidikan tinggi sebagai transformasi pembangunan. Lebih fokusnya mengkaji apa yang menjadi peluang dan tantangan untuk pembangunan Aceh Barat pada sektor pendidikan? Mengapa pembangunan di sektor pendidikan 
menjadi penting? apa dan bagaimana peran akademisi pada pembangunan pada sektor pendidikan?

Untuk menjelaskan kajian ini, penulis mencoba menggunakan pendekatan improvement approach dan tranformation approach (Soetomo, 2008), penulis mengamati bahwa pembangunan pada sektor pendidikan di Aceh Barat saat ini sedang mengalami proses perubahan, artinya bahwa beberapa tahun terakhir pembangunan di sektor pendidikan mengalami kemandekan, namun saat ini pembangunan pada sektor pendidikan sedang mengalami proses perubahan yang cukup baik. Jika pembangunan di sektor pendidikan berjalan dengan baik, maka akan berdampak baik terhadap pembangunan disektor yang lain. Oleh karena itu pendidikan menjadi hal sangat penting, pendidikan merupakan ujung tombak pembangunan sektor lainnya.

Improvement approach merupakan pendekatan yang lebih soft dibandingkan dengan pendekatan transformation approach yang lebih radikal. Transformation approach merupakan perubahan yang dilakukan melalui perubahan level struktur, sistem dan institusi sosial. sedangkan improvement approach merupakan pendekatan yang lebih soft dan tidak melakukan perubahan pada level struktur tetapi hanya memanfaatkan potensi yang sudah ada pada masyarakatnya kemudian melakukan perubahan secara berangsur-angsur dan perlahan-lahan (Soetomo, 2008). Improvement approach mendorong perubahan dalam berbagai segmen kehidupan masyarakat, tetapi masih memberikan toleransi pada struktur yang telah ada (Soetomo, 2009). Dixon (1990) dalam (Soetomo, 2008) menjelaskan bahwa pendekatan transformation approach yaitu sebagai pendekatan radikal berorientasi pada ideologi sosialis, sedangkan improvement approach yaitu sebagai pendekatan reformis berorientasi pada ideologi nasionalis.

Pada proses pembangunan perubahan sikap menjadi hal yang sangat penting, Koentjaraningrat dalam (Soetomo, 2009), cenderung menggunakan konsep sikap mental yaitu perpaduan "konsep sikap" dan "konsep sistem nilai". Menurutnya sikap didasarkan pada orientasi nilai budaya, maka perubahan sikap identik dengan perubahan kultural. Perubahan sikap yang berorientasi pada sistem nilai budaya merupakan pandangan "perspektif kultural" menganggap bahwa keterbelakangan yang terjadi di beberapa negara berkembang disebabkan oleh kultural masyarakatnya, berbeda dengan perspektif struktural yang menganggap keterbelakangan yang terjadi di beberapa negara berkembang disebabkan oleh struktural (Soetomo, 2009). Jika mengamati Aceh Barat dan 
34

Community: Volume 4, Nomor 1, April 2018

ISSN: $2477-5746$

Barsela tentu saja ketertinggalan pembangunan disebabkan oleh berbagai faktor yaitu kultural dan juga struktural. Kegagalan dan suksesnya pembangunan tidak dapat dilihat dari salah satu aspek saja, namun segala aspek sangat berpengaruh terhadap sukses atau gagalnya pembangunan.

\section{METODE PENELITIAN}

Tulisan ini menggunakan penelitian kepustakaan, namun juga di dukung oleh data-data sebelumnya melalui wawancara dan observasi yang peneliti dapatkan saat penelitian terdahulu tentang topik-topik yang berbeda, misalnya penelitian tentang pembangunan, penelitian tentang masyarakat dan pendidikan. Data-data mentah hasil penelitian tersebut sangat membantu penulis dalam menganalisis tulisan ini.

\section{TEMUAN DAN PEMBAHASAN}

Aceh Barat merupakan salah satu kabupaten dari 23 kabupaten/kota yang ada di provinsi Aceh saat ini, Aceh Barat terletak di 0406' - 04 ${ }^{\circ} 47^{\prime}$ Lintang Utara, 9552' - 96³0' Bujur Timur dan luas wilayahnya 2927,95 Km², Aceh Barat memiliki Ibu Kota yaitu Meulaboh. Batas-batas wilayahnya adalah sebelah utara berbatasan dengan Kabupaten Aceh Jaya dan Kabupaten Pidie, sebelah selatan berbatasan dengan Samudera Indonesia dan Kabupaten Nagan Raya, sebelah timur berbatasan dengan Kabupaten Aceh Tengah dan Kabupaten Nagan Raya, sebelah barat berbatasan dengan Samudera Indonesia. Aceh Barat saat ini memiliki 322 Gampong (Desa), 32 Kemukiman dan 12 Kecamatan. (http:/ /acehbaratkab.go.id/profil/geografis diakses tanggal 30 Oktober 2017).

Isu-isu pembangunan, ketimpangan dan kemiskinan bukanlah isu-isu yang baru, melainkan isu-isu yang telah lama dan usang, sekalipun demikian isu-isu kemiskinan dan pembangunan masih relevan untuk terus dikaji mengingat sampai hari ini kita terbukti belum mampu menyelesaikan persoalan-persoalan kemiskinan, ketimpangan dan pembangunan di negeri ini. Berbagai teori lahir dalam keilmuan sosiologi mulai dari klasik hingga postmodern, namun sampai sekarang ini kita hanya mampu berbicara dan memberikan sumbangsih berupa gagasan dan teori, namun belum mampu menyelesaikan persoalan secara praktis dan menyeluruh. Hal ini merupakan tantangan yang besar bagi pegiat di bidang sosial, baik para akademisi maupun para praktisi. 
Penulis bukan bermaksud untuk menyalahkan para ahli yang telah melahirkan berbagai teori tentang pembangunan dan telah berusaha menyelesaikan persoalan-persoalan kemiskinan, banyak hal yang telah mereka sumbangkan, namun tentu saja ada berbagai persoalan yang kemudian pembangunan dan penanggulangan kemiskinan menjadi terhambat, mulai dari sistem birokrasi pemerintahan di negeri ini sampai pada perubahan-perubahan sosial yang terus bergerak dalam kehidupan masyarakat kita. Persoalan-persoalan di negeri ini terus bertambah seiring dengan perkembangan zaman dan di dukung oleh teknologi informasi yang merupakan salah satu ciri-ciri globalisasi.

Pembangunan tentu saja memiliki peluang dan tantangan, begitu juga ketika kita bawa dalam arena pembangunan di Aceh Barat. Aceh Barat hari ini sedang gencar-gencar melakukan pembangunan dalam berbagai aspek, terutama dibidang pendidikan, Aceh Barat hari ini memiliki tiga perguruan tinggi negeri yang akan memberikan dampak yang sangat baik untuk pembangunan Aceh Barat dan Barsela di masa yang akan datang. Perguruan tinggi merupakan aset yang paling utama untuk menciptakan generasi yang berkualitas dimasa yang akan datang. Aceh Barat ke depannya akan menjadi pusat peradaban pendidikan yang baru setelah Kota Banda Aceh, Aceh Barat akan menjadi "kota pelajar" yang kedua setelah Kota Banda Aceh. ini merupakan mimpi besar yang akan terwujud dalam beberapa tahun ke depan. Jika Banda Aceh memusatkan "kota pelajar" di Kecamatan Syiah Kuala-Darussalam, maka Aceh Barat akan memusatkan "kota pelajar" di Kecamatan Meureubo, di sana terdapat tiga perguruan tinggi negeri, yaitu Universitas Teuku Umar dan STAIN Tengku Dirundeng dalam proses pembangunan infrastrukturnya, Akademi Komunitas Negeri juga berada di Kecamatan yang sama.

Bagi masyarakat Aceh Barat, pembangunan di bidang pendidikan ini merupakan salah satu cara untuk mengembangkan Aceh Barat itu sendiri terutama di bidang pendidikan yang berkualitas dan kemudian bermanfaat bagi kehidupan masyarakat. Pendidikan tinggi yang baru saja didirikan telah memberikan peluang yang seluas-luas bagi masyarakat Aceh Barat untuk menempuh pendidikan tinggi, berbagai program studi telah di tawarkan oleh perguruan tinggi, calon mahasiswa tinggal memilih bidang yang diminatinya.

Tantangannya kemudian adalah perguruan tinggi negeri telah hadir di tengah-tengah kehidupan masyarakat, peluang telah terbuka lebar, namun apakah masyarakat Aceh Barat dan Barsela akan memanfaatkan peluang itu? ataukah 
sebaliknya, masyarakat luar Aceh Barat dan Barsela yang kemudian memanfaatkan dan menangkap peluang itu? Jika peluang itu bisa di manfaatkan oleh masyarakat Aceh Barat dan Barsela, tentu saja sepuluh sampai lima belas tahun yang akan datang, Aceh Barat dan Barsela secara umum akan memiliki sarjana-sarjana yang unggul di berbagai bidang. Sarjana-sarjana ini kemudian akan menciptakan lapangan kerja dan tentu saja memberikan sesuatu yang terbaik untuk wilayah Barsela terutama Aceh Barat.

Persoalannya kemudian adalah minat masyarakat Aceh Barat terhadap pendidikan tinggi khususnya kelas menengah ke bawah, belum mampu menunjukkan sesuatu yang memuaskan, kelas menengah keatas pada umumnya akan menempuh pendidikan tinggi di luar Aceh Barat (Jarmita, 2006). Lokasi pendidikan tinggi yang paling dekat mereka pilih pada umumnya adalah Kota Banda Aceh, selain itu juga beberapa kota yang telah terkenal kemajuannya dibidang pendidikan tinggi, yaitu: Yogyakarta, Jakarta, Bogor, Bandung, Medan dan Padang. Alasan mereka tentu saja beragam, mulai dari kualitas pendidikan tinggi yang telah jauh lebih maju dibandingkan dengan Aceh Barat. Setelah selesai dari pendidikan tinggi pada umumnya mereka akan memilih untuk merantau dibandingkan untuk kembali ke Aceh Barat, dampaknya kemudian adalah sarjana-sarjana unggul ini akan sedikit sekali memberikan sumbangsih bagi pembangunan Aceh Barat sendiri.

Kelas menengah kebawah, jarang sekali melanjutkan pendidikan sampai perguruan tinggi, jika pun ada persentase dinilai masih tergolong sangat kecil, mengapa? Mereka menganggap untuk menempuh pendidikan tinggi perlu biaya yang sangat besar. Padahal hari ini berbagai beasiswa dapat dimanfaatkan oleh mahasiswa baru, mulai dari LPSDM Aceh sampai pada beasiswa bidikmisi dari Kementerian Riset, Teknologi dan Pendidikan Tinggi. Semua jenis beasiswa itu hadir untuk memberikan kemudahan bagi mahasiswa baru yang akan menempuh pendidikan tinggi. Tidak ada alasan untuk tidak menempuh pendidikan tinggi, kemudahan-kemudahan telah diberikan oleh pemerintah, belum lagi beasiswa Pemda masing-masing daerah. Biaya pendidikan (SPP) untuk mahasiswa saat ini juga disesuaikan dengan pendapatan orang tua masing-masing mahasiswa yang dikenal dengan UKT (Uang Kuliah Tunggal), jadi sebenarnya tidak ada yang memberatkan lagi untuk menempuh pendidikan di perguruan tinggi. Informasi ini terkadang tidak tersampaikan pada masyarakat kelas menengah kebawah, mereka masih berfikir untuk menempuh pendidikan tinggi membutuhkan biaya yang 
besar. Hari ini perguruan tinggi negeri telah hadir di Aceh Barat, arena pertarungan telah dibuka, tinggal saja bagaimana masyarakat khususnya pemuda harus mampu bertarung dalam arena tersebut untuk merebut kesuksesan dan kejayaan di masa yang akan datang, sekaligus memberikan yang terbaik untuk pembangunan Aceh Barat.

Jika masyarakat Aceh Barat dan Barsela tidak mampu memanfaatkan peluang ini, maka bersiap-siaplah untuk terus mengalami ketertinggalan dibidang pendidikan. Masyarakat luar akan meneropong peluang ini, apalagi hari ini perguruan tinggi negeri di Aceh Barat juga telah dibidik oleh para mahasiswa dari luar Aceh Barat dan Barsela, tentu saja dengan beragam alasan. Situasi ini kemudian berdampak pada kondisi sosial masyarakat, masyarakat Aceh Barat dan Barsela nantinya akan menjadi penonton di negerinya sendiri, dalam pepatah Aceh dikenal dengan istilah "Buya Krueng Teu Dong-Dong, Buya Tameng Meuraseuki". Banyak realita yang telah kita amati, misalnya siapakah yang kuliah di Banda Aceh? apakah masyarakat Banda Aceh atau Aceh Besar? Begitu juga di beberapa kota di Indonesia, misalnya Yogyakarta, Jakarta, Bandung, Bogor, pada umumnya mahasiswa berasal dari luar daerah, masyarakat setempat akan menjadi penonton di negerinya sendiri.

Hadirnya perguruan tinggi di Aceh Barat juga akan berdampak pada perekonomian masyarakat Aceh Barat, perputaran ekonomi akan berjalan dengan baik, jika wilayah Aceh Barat menjadi "kota pelajar". Berbagai kebutuhan pokok dapat dipasarkan, jajanan untuk para mahasiswa, warung nasi, warung kopi, toko percetakan dan ATK, perbengkelan, toko rempah-rempah, pasar ikan. Perekonomian ini akan terus berputar seiring dengan kemajuan di bidang pendidikan dan perkembangan perguruan tinggi. Kehadiran perguruan tinggi memberikan dampak yang luar biasa bagi perekonomian Aceh Barat. Kehadiran pendatang baru, baik mahasiswa, dosen, pegawai mereka semuanya akan memyumbang bagi kemajuan Aceh Barat. Ada kehidupan yang saling berpengaruh dan saling menguntungkan, mahasiswa yang belajar, dosen dan pegawai yang bekerja di perguruan tinggi tentu saja butuh pasar untuk membeli kebutuhan sehari-hari, pedagang yang menjaja dagangannya juga butuh mahasiswa, dosen, pegawai sebagai pembeli. Selain usaha-usaha rumah kontrakan juga akan semakin berkembang dan bertambah seiring bertambahnya jumlah mahasiswa, dosen, pegawai di Aceh Barat. 
Saat ini minat masyarakat Aceh Barat untuk melanjutkan ke perguruan tinggi masih dinilai kurang, dan hal ini menjadi pekerjaan rumah yang cukup besar bagi akademisi di perguruan tinggi, dibeberapa daerah sebelumnya terlihat akademisi belum mampu merubah minat masyarakat akan pendidikan tinggi. Lalu apa dan bagaimana peran akademisi untuk meningkatkan minat masyarakat Aceh Barat akan pendidikan tinggi? Hal ini penting, agar tidak terjadi ketimpangan di bidang pendidikan, masyarakat Aceh Barat harus benar-benar merasakan dampak yang positif dengan kehadiran berbagai perguruan tinggi negeri.

Sebagai akademisi, maka memiliki peran untuk meningkatkan pendidikan, penelitian dan pengabdian masyarakat sesuai dengan tridarma perguruan tinggi. Pendidikan akan terus dilakukan di dalam kampus sesuai dengan kurikulum yang berlaku, kampanye tentang pendidikan tinggi juga sangat penting dilakukan diluar kampus, misalnya melalui baliho, spanduk, dan juga kampanye di radio, tujuannya adalah agar masyarakat akrab dengan dunia pendidikan tinggi dan yang paling penting adalah menyadarkan masyarakat untuk memahami akan pentingnya pendidikan tinggi sekaligus membuang jauh-jauh pikiran yang telah tertanam bahwa untuk melanjutkan pendidikan tinggi akan mengeluarkan biaya yang tidak sedikit. Peran akademisi sangat penting untuk merubah pemahaman dan minat masyarakat akan pendidikan tinggi, jika tidak dilakukan, maka dikhawatirkan masyarakat Aceh Barat akan mengalami ketertinggalan dibidang pendidikan dan pada akhirnya berdampak pada sektor-sektor yang lain, karena yang paling utama harus diperbaiki adalah pendidikan. Pendidikan merupakan ujung tombak pembangunan, jika pendidikannya berjalan dengan baik, dapat dipastikan pembangunan di sektor yang lain juga akan berjalan dengan baik.

Penelitian juga harus terus dilakukan, penelitian-penelitian dibidang sosial dinilai cukup penting saat ini, pemetaan terhadap kondisi sosial masyarakat Aceh Barat dinilai sangat penting, agar memahami bagaimana sesungguhnya masyarakat Aceh Barat saat ini. Ketika akademisi telah memahami kondisi masyarakatnya, maka akan mudah dan akan tepat sasaran untuk melakukan berbagai intervensi kebijakan dan program-program pengabdiannya bagi masyarakat Aceh Barat. Pengabdian juga harus terus dilakukan oleh para akademisi dan juga mahasiswa, melalui berbagai program pengabdian diharapkan mampu memberikan yang terbaik bagi masyarakatnya, terutama sekali adalah merubah pola pikir masyarakat, bahwa pendidikan tinggi sangat penting. Selain 
itu melalui berbagai program pengabdian ini, secara tidak langsung merupakan arena kampanye dan memperkenal pendidikan tinggi kepada masyarakatnya.

Sebagian para akademisi mungkin saja tidak sadar bahwa saat ini ada tantangan yang cukup besar hadir ditengah-tengah dan dilingkungan perguruan tinggi. tantangannya adalah masyarakat yang belum sadar akan pentingnya pendidikan tinggi, sekilas mungkin saja kita melihat hal ini adalah biasa saja, tetapi sesungguhnya hal ini tidak hanya sekedar tantangan, namun juga ancaman yang cukup serius yang akan mengganggu keharmonisan masyarakatnya yang hidup dalam multikultural, ketimpangan pendidikan justru akan terjadi, kecemburuan sosial akan hadir secara perlahan-lahan, lalu kriminal juga akan datang seiring dengan ketimpangan pendidikan dan kecemburuan sosial tadi.

Peran akademisi lainnya adalah akademisi harus mampu bekerjasama dengan pemerintah daerah untuk memajukan pendidikan. Pada masa pemerintahan sebelumnya pemerintah telah berhasil mengembangkan program pembangunannya melalui pendidikan dengan diresmikannya tiga perguruan tinggi negeri. Hubungan yang baik antara akademisi dan pemerintah daerah harus terus dibangun, berbagai program pendidikan harus berjalan secara sinergi dan terintegrasi, berbagai program pembangunan harus dimulai dengan perencanaan yang baik dan memiliki data. Segala intervensi pembangunan harus berdasarkan kebutuhan masyarakatnya bukan keinginan para penguasa. Program-program pembangunan harus banyak mengarahkan pada pendidikan, sosial, ekonomi, bukan hanya pada pembangunan infrastruktur semata.

Saat ini peran akademisi dalam pembangunan pendidikan di Aceh dinilai cukup baik, tri dharma perguruan tinggi telah mulai berproses dengan baik, penelitian dan pengabdian telah banyak dilakukan oleh para akademisi yang telah memberikan sumbangsih pada perkembangan pembangunan di Kabupaten Aceh Barat dan Barsela pada umumnya. Penulis mengamati Kuliah Kerja Nyata mahasiswa sudah mulai berjalan dengan baik, pengabdian para akademisi di berbagai sektor juga sudah mulai hadir dalam kehidupan masyarakat. Penelitianpenelitian akademisi tentang kondisi sosial masyarakat juga telah mulai dilakukan untuk memetakan kondisi masyarakat agar intervensi pembangunan dapat berjalan dengan baik. 
40

Community: Volume 4, Nomor 1, April 2018

ISSN: $2477-5746$

\section{Kesimpulan}

Pendidikan tinggi merupakan salah satu motor penggerak pembangunan, kemajuan suatu daerah akan dimulai dari majunya pendidikan. Saat ini Aceh Barat merupakan wilayah yang sedang berbenah, Aceh Barat merupakan lokomotif untuk kemajuan Barsela, Aceh Barat satu-satunya kabupaten yang memiliki perguruan tinggi negeri yang akan berdampak positif pada kemajuan Barsela. Peran akademisi dinilai sangat penting untuk memajukan pendidikan dan mengajak masyarakat Aceh Barat untuk memajukan pendidikan, terutama pendidikan tinggi. Akademisi harus mampu merubah pola pikir masyarakat yang saat ini minat masyarakat terhadap perguruan tinggi dinilai masih kurang.

Sinergitas antara akademisi dan pemerintah daerah juga harus berjalan dengan baik, berbagai program pembangunan harus terintegrasi dengan baik, segala program pembangunan harus dimulai dengan data-data penelitian, agar pembangunan berjalan sesuai dengan kebutuhan masyarakat, bukan kepentingan para pengusaha dan penguasa. Program-program pembangunan harus diarahkan pada pembangunan pendidikan, sosial dan ekonomi, tidak hanya pada pembangunan infrastruktur semata.

\section{Daftar Pustaka}

Soetomo. (2008). Strategi-strategi Pembangunan Masyarakat (2nd ed.). Yogyakarta: Pustaka Pelajar.

Soetomo. (2009). Pembangunan Masyarakat; Merangkai Sebuah Kerangka (1st ed.). Yogyakarta: Pustaka Pelajar.

Syahputri, V. N., \& Liyana, C. I. (2017). Partisipasi Masyarakat Gampong Dalam Pembangunan Pasca Lahirnya UU Desa No. 6 Tahun 2014, (6), 89-109.

Syarifuddin, T. (2016). Kontribusi Perguruan Tinggi dalam Proses Pembangunan Bidang Kesejahteraan Sosial, 9, 86-100.

Vina Salviana Darvina Soedarwo, Nurul Zuriah, Ratih Yuliati, S. (2017). 
Community: Volume 4, Nomor 1, April 2018

ISSN: $2477-5746$

Pemberdayaan Masyarakat melalui pendidikan non formal Berbasis Potensi Lokal Dalam Membangun Desa Wisata Adat. Jurnal Sosiologi Pendidikan Humanis, 96-102.

http:/ /acehbaratkab.go.id/profil/geografis diakses tanggal 30 Oktober 2017

Jarmita, Nida. 2016. Pemahaman Masyarakat Terhadap Pendidikan; Suatu Studi pada Masyarakat Asoe Lhok di Aceh Barat. Banda Aceh: IAIN-Ar-Raniry. 